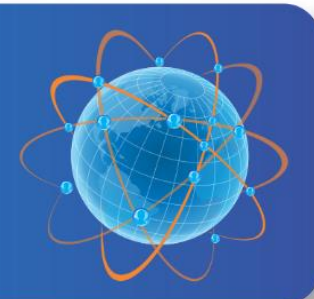

\title{
LITERASI DIGITAL DAN PEMBUKAAN DIRI: Studi Korelasi Penggunaan Media Sosial Pada Pelajar Remaja di Kota Medan
}

Authors : Stella Stefany, Nurbani, Badarrudin

Published by : Departemen of Sociology, Faculty of Social and Political Science, Universitas Padjadjaran

Accepted : October 2017; Approved : December 2017

Sosiogobal: Jurnal Pemikiran dan Penelitian Sosiologi is the Department of Sociology, Faculty of Social and Political Science, Universitas Padjadjaran flagship journal. The Sosioglobal journal founded in 2016 with the mission to publish original works of interest to the discipline of sociology in general, sociological thinking, new theoretical developments, results of research that enhance understanding of fundamental social processes, and methodological innovations. We are welcome a research article, working paper, theoretical/conceptual and methodological review to submit to our journal. In addition, we are accept relevant book review that currently publish and enrich sociological perspectives. Please submit article to http://jurnal.unpad.ac.id/sosioglobal

To cite this article :

Stefany, Stella, Nurbani and Badarrudin. 2017. Literasi Digital dan Pembukaan Diri : Studi Korelasi Penggunaan Media Sosial Pada Pelajar Remaja di Kota Medan. Sosioglobal : Jurnal Pemikiran dan Penelitian Sosiologi 2(1):10-31. 


\title{
LITERASI DIGITAL DAN PEMBUKAAN DIRI: Studi Korelasi Penggunaan Media Sosial Pada Pelajar Remaja di Kota Medan
}

\author{
Stella Stefany ${ }^{1}$, Nurbani ${ }^{2}$, Badarrudin ${ }^{3}$ \\ Magister Ilmu Komunikasi, Fakultas Ilmu Sosial Ilmu Politik, Universitas Sumatera Utara \\ stella.stefany@yahoo.com
}

\begin{abstract}
ABSTRAK
Tujuan dari penelitian ini adalah untuk menganalisis korelasi antara literasi digital dan pembukaan diri pelajar remaja sebagai pengguna media sosial. Penelitian ini menggunakan metode kuantitatif dengan pendekatan komparasi deskriptif. Teknik pengambilan sampel menggunakan metode Purposive Sampling. Besaran populasi induk adalah 7399 siswa di 20 SMA di Kota Medan. Sampel penelitian menggunakan perhitungan Tabel Taro Yamane dan menghasilkan 378 responden yang secara proporsional di Kecamatan Medan Kota sebagai pengguna media sosial. Kuesioner literasi digital terdiri dari 17 butir pertanyaan dan kuesioner pembukaan diri di media sosial diadposi dari penelitian terdahulu Revised Self Disclosure Scale (Blau, 2011) yang telah direvisi dan menghasilkan 17 butir pertanyaan dengan pilihan jawaban menggunakan skala Likert (1-4). Temuan dalam penelitian ini adalah adanya korelasi positif antara variabel X dan Y (Literasi Digital dan pembukaan diri di media sosial) dengan skala sedang.
\end{abstract}

Kata Kunci : literasi digital, pembukaan diri, remaja, media sosial, kota medan

\begin{abstract}
The purpose of this research is to analyze the correlation between digital literacy and self-disclosure in adolescence students as the active user of social media. This is quantitative research with comparative descriptive approach. By using purposive sampling technique, the researcher has ideally figured the major population size in Medan, and decided that every element or element group must have equal probability to be treated as a sample. The sample is counted using the Taro Yamane Table, resulting in 378 respondents consisting of active social media users that are proportionally spread around 20 high schools in the district of Medan Kota. The researcher uses questionnaire as the data collection method. The digital literacy questionnaire consists of 17 questions while the questionnaire on the matter of selfdisclosure on social media is adopted from a previous study titled Revised Self Disclosure Scale (Blau, 2011), using the Likert scale for answering options. The findings in this research are the positive correlation between the $\mathrm{X}$ and $\mathrm{Y}$ variables (digital literacy and self-disclosure on social media) on a medium scale.
\end{abstract}

Keywords : digital literacy, self disclosure, adolescences, students, social media

2,3. Magister Ilmu Komunikasi, Fakultas Ilmu Sosial Ilmu Politik, Universitas Sumatera Utara 


\section{PENDAHULUAN}

Perkembangan teknologi yang begitu pesat terjadi dalam satu dekade terakhir, dimana teknologi layar sentuh muncul sebagai barang mewah, hingga pada saat ini gawai menjadi benda yang bisa dimiliki oleh siapa saja, dari kelas ekonomi sosial manapun. United States Cencus Bureau (2016) mencatatkan mayoritas penduduk dunia saat ini ditempati oleh Generasi Z $(34 \%)^{1}$. The Research Center of Generational Kinetics menuliskan manusia yang tergolong dalam Generasi Z adalah mereka yang lahir pada tahun 1996-2009 (usia 8-21 tahun pada tahun 2017$)^{2}$. Rentang usia 8-21 tahun ini adalah usia sekolah pada umumnya. E-school News $(2009)^{3}$ mencatatkan beberapa perusahaan teknologi seperti Verizon, Dell, Apple dan Microsoft mendukung pendanaan e-learning, dimana dunia pendidikan pun harus ikut beralih ke era digital. Kemudahan yang diberikan oleh peralihan ke era digital ini dapat sangat dinikmati oleh generasi Z ini. Remaja sebagai bagian besar dari Generasi Z ini merupakan pengguna yang aktif. Seperti dicatatkan pada riset Komunfo dan UNICEF (2016) ${ }^{4}$, setidaknya ada 30 juta anak-anak dan remaja di Indoneisa yang menjadi pengguna internet dan menjadikan media digital ini sebagai pilihan utama saluran komunikasi yang mereka gunakan.

Christensen $(2011)^{5}$ menyatakan dampak negatif bermedia sosial sangat potensial dialami oleh remaja. Hurlock (2011:16) ${ }^{6}$ menyatakan bahwa masa remaja adalah masa transisi perkembangan antara masa kanak-kanak dan dewasa yang pada umumnya dimulai pada usia 12-13 tahun dan berakhir pada akhir belasan tahun. Beliau juga membagi masa remaja dalam dua bagian, (1) remaja awal: 13-16 tahun dan (2) remaja akhir: 16-18 tahun. Hurlock membuat kedua perbedaan ini karena pada masa remaja akhir, individu telah mencapai masa transisi perkembangan yang lebih mendekati masa dewasa. Bagi mereka (remaja), gawai bukan lagi berfungsi sebagai asisten yang serba bisa, namun gawai bisa menjadi alat bantu aktualisasi diri mereka.

\footnotetext{
${ }^{1}$ World Population Based On Generation. (2016). United States Cencus Bureau Diunduh pada 13 November 2016 dari https://www.linkedin.com/pulse/worlds-population-just-passed-75-billion-here-some-fascinating-kemp

2 Pembagian Generasi Berdasarkan Tahun Lahir (Infographics on Millennials, Gen Z, and Generations). Diunduh pada 13 November 2016 dari http://genhq.com/findings/

${ }^{3}$ New Standards to Facilitate eLearning. 31 Maret 2009. Diakes pada 13 Desember 2017 dari

https://www.eschoolnews.com/2009/03/31/new-standards-to-facilitate-elearning/

${ }^{4}$ Riset Kominfo dan UNICEF Mengenai Perilaku Anak dan Remaja Dalam Menggunakan Internet. (6 Juli 2016). Diunduh pada 31 Maret 2017 dari https://www.kominfo.go.id/content/detail/3834/siaran-pers-no-17pihkominfo22014-tentang-riset-

kominfo-dan-unicef-mengenai-perilaku-anak-dan-remaja-dalam-menggunakan-internet/0/siaran_pers

${ }^{5}$ Christensen. (2011). "You're the only person i can talk to" the role of self-disclosure in the social construction of friendship.

Journal of Undergranate Research

${ }^{6}$ Hurlock, E.B. (2011). Developmental Psychology. New York : McGraw-Hill.
} 
Dalam dunia digitalisasi ini, James $(2014)^{7}$ dan internetlivestats.com ${ }^{8}$ mencatatkan banyaknya informasi yang beredar di internet sudah mencapai angka yang sangat fantastis sehingga masuk dalam kategori kelebihan informasi (Information Overload). Paul Virilio (dalam Jungwirth, $2002^{9}$ menyebutkan kelebihan informasi sebagai bom informasi yang akan berdampak pada dehumanisasi, yang pada akhirnya akan menyebabkan kesulitan bagi individu untuk mencari informasi yang benar-benar bernilai. Penelitian dari Kusumaningtyas (2010) ${ }^{10}$ mencatatkan Komnas HAM melaporkan ada lebih dari 100 anak hilang akibat menjalin pertemanan melalui media sosial dengan korban mayoritas adalah remaja putri. Peran media sosial sangat besar bagi saluran pembukaan diri remaja putri karena mampu membuat informasi tersembunyi di kehidupan nyata cenderung diungkapkan di media sosial secara terbuka oleh pengguna media sosial tersebut. Kasus kekerasan pada dunia nyata banyak disebabkan oleh pembukaan diri secara online yang kurang tepat. Eurobarometer (2011) ${ }^{11}$ mencatatkan 68\% penduduk Jerman dan 63\% penduduk Eropa menyatakan bahwa keterbukaan informasi online saat ini menjadi hal yang sangat serius. Jackson dan Wang (2013) ${ }^{12}$ menuliskan bahwa penduduk dengan tingkat individualistis tinggi memiliki tingkat pembukaan diri yang lebih rendah dibanding budaya kolektivistik dalam kehidupan sosialnya.

Oktober 2016, detiknews ${ }^{13}$ menuliskan berita dengan caption "Saling Ejek di Medsos, Mahasiswi Lukai Siswi SMA Pakai Silet”. Kompas ${ }^{14}$ juga melansir berita sejenis pada tahun sebelumnya, "Gara-Gara Facebook, Siswi SMP Ditikam Siswi SMA". Pada bulan yang sama, Kompas e-news juga memberitakan tentang kasus pemerkosaan siswi SMA akibat kenalan di Facebook. Media elektronik lainnya melansir berita tentang Marietta Nova Triana $(14)^{15}$, siswi salah satu SMP di Surabaya menghilang dari rumahnya dan ditemukan sedang bersama Ari, pemuda yang dikenalnya melalui media sosial dan menyatakan telah mengalami pencabulan sebanyak tiga kali.

\footnotetext{
7 James, J. (2014). Data never sleeps 2.0. diunduh tanggal 13 Desember 2016 dari https://www.domo.com/blog/data-neversleeps-2-0/

8 Internet users in the world. Diunduh pada 30 November 2016 dari www.internetlivestats.com

9 Jungwirth, Bernhard (2002), Information Overload: Threat or Opportunity?

http:// citeseerx.ist.psu.edu/viewdoc/download?doi=10.1.1.461.2076\&rep=rep1\&type=pdf diakses tanggal 2 April 2017

${ }^{10}$ Kusumaningtyas, R.D. (2010). Peran Media Sosial Online Facebook Sebagai Saluran Self Disclosure Remaja Putri di

Surabaya. Skripsi Universitas Pembangunan Negara.

${ }_{11}$ Eurobarometer Research of Self Disclosure between Germany and European. (20 Agustus 2011) diakses pada 3 Januari 2017 dari http://ec.europa.eu/commfrontoffice/publicopinion/archives/ebs/ebs_359_en.pdf

12 Jackson \& Wang. (2013). Youth 2.0: Social Media and Adolescence: Connecting, Sharing and Empowering. Switzerland : Springer.

${ }^{13}$ Saling Ejek di Medsos, Mahasiswi Lukai Siswi SMA Pakai Silet diakses pada 13 Februari 2017 dari http://news.detik.com/berita/d-3313474/saling-ejek-di-medsos-mahasiswi-lukai-siswi-sma-pakai-silet

${ }^{14}$ Kenalan di Facebook, SA Perkosa Siswi SMA. (13 Mei 2016) diunduh pada 13 Februari 2017 dari : http://regional.kompas.com/read/2016/05/13/09090021/Kenalan.di.Facebook.SA.Perkosa.Siswi.SMA

${ }^{15}$ Korban Penculikan Lewat Facebook (9 Februari 2010) diunduh dari http://www.viva.co.id/berita/metro/127827-korbanpenculikan-lewat-facebook ditemukan
} 
Kasus-kasus yang marak dialami remaja melalui media sosial, ditengarai berawal dari pembukaan diri di media sosial yang dipublikasikan oleh remaja tersebut. Pemahaman yang cukup tentang dunia digital (literasi digital) dan keterbukaan informasi diri remaja di media sosial diduga akan memiliki keterkaitan. Kasus-kasus yang memberikan dampak negatif pada penggunaan media sosial seringkali dialami oleh remaja karena ketidakmatangan remaja dalam mengenali identitas diri maupun lingkungannya. Penelitian ini akan menjawab pertanyaan tentang korelasi antara literasi digital dan pembukaan diri di media sosial pada pelajar remaja di Medan dengan budaya kolektivistis yang sangat tinggi.

\section{METODE PENELITIAN}

Penelitian ini akan menggunakan metode penelitian kuantitatif dengan pendekatan eksplanatif dan menggunakan teknik purpossive sampling. Dari 21 Kecamatan di Kota Medan, Kecamatan Medan Kota memiliki jumlah SMA terbanyak dengan total 20 SMA dan 7399 pelajar (BPS Kota Medan, 2016). Pengambilan sampel menggunakan Tabel Taro Yamane dengan presisi 5\% menghasilkan angka 378. Kuesioner akan dibagikan secara proporsional ke 20 SMA di Kecamatan Medan Kota. Dalam penelitian ini, peneliti menggunakan satu kuesioner yang terdiri dari dua bagian yang mewakili variabel penelitian. Seperti yang telah dijelaskan diatas, kuesioner literasi digital disusun sendiri oleh penulis, sementara variabel self disclosure online akan menggunakan Revised Self-disclosure Scale, yang diadaptasi dari desertasi Leung (2002) ${ }^{16}$ yang berjudul "Depth, Honesty and Intention" diterbitkan oleh Mary Ann Liebert, Inc. Setelah melakukan proses back translate, peneliti mengeliminasi pertanyaan yang dianggap kurang sesuai dengan konteks dimana penelitian ini dilakukan dan menambahkan beberapa pertanyaan untuk memperkaya data sesuai dengan definisi operasional dari dimensi variabel.

Dengan total 378 responden, peneliti melakukan dua pendekatan yang berbeda untuk mendapatkan data. Untuk responden yang berjumlah lebih dari 50 orang dalam satu sekolah, peneliti mengurus ijin formal untuk membagikan kuesioner langsung kepada siswa dengan batasan waktu 15 menit. Untuk responden yang lebih sedikit, peneliti memberikan langsung kepada siswa yang bersangkutan secara acak dengan menunggu waktu kepulangan sekolah (pembagian kuesioner setelah jam sekolah dilakukan di luar sekolah). Pengumpulan data ini dilaksanakan pada tanggal 24 Juli - 7 Agustus 2017.

Uji reliabilitas akan menggunakan jenis internal consistency yaitu menggunakan satu alat tes pada satu waktu atau biasa disebut dengan single trial administration. Teknik uji yang digunakan adalah dengan Spearman-Brown, Kuder-Richardson dan Alpha Cronbach. Teknik ini dilakukan

${ }^{16}$ Leung,L. (2002). Loneliness, Self-Disclosure, and ICQ ("I Seek You”) Use. CyberPsychology and Behavior : Mary Ann Liebert, Inc. 
karena skor yang dihasilkan adalah tingkat, bukan tipe. Artinya alat ukur memiliki satu atau lebih dimensi, namun mengukur hal yang sama.

Bersamaan dengan itu, pengujian ini juga memperhatikan nilai validitas pada masing-masing butir pertanyaan. Nilai minimal validitas butir pertanyaan yang disarankan adalah 0.2, sedangkan nilai minimal reliabilitas dimensi atau alat ukur yang disarankan adalah 0.6. Jika pada kolom corrected item - total correlation terdapat nilai validitas yang kurang dari 0.2 maka butir tersebut akan dieliminasi. Eliminasi akan dilakukan satu per satu dimulai dari yang nilainya paling kecil (nilai negatif diperhitungkan sebagai nilai yang lebih kecil). Kuesioner yang sudah disusun dibagikan ke $\pm 10 \%$ total responden yang akan digunakan yaitu 40 orang dengan kriteria responden yang sesuai dan tersebar di luar wilayah Kecamatan Medan Kota untuk diuji reliabilitas dan validitasnya.

Pengolahan hasil penelitian akan menggunakan statistik inferensial. Menurut Bungin (2011), Metode statistik inferensial adalah alat yang dipakai dalam membuktikan kebenaran teori probabilitas yang umumnya digunakan dalam penelitian dengan tujuan eksplanasi. Metode ini digunakan juga untuk menguji hipotesis penelitian dengan taraf signifikansi 5\% yang berarti taraf kepercayaannya adalah 95\%.

Namun sebelumnya, peneliti melakukan uji normalitas data. Peneliti menggunakan metode Saphiro-Wilk dalam uji normalitas data ini. Selanjutnya sebagai profil responden, peneliti melakukan uji univariat (tabel frekuensi) untuk jenis kelamin dan usia, kemudian analisa univariat ini juga dilakukan untuk dimensi kedua variabel. Tabel silang pun dilakukan jika diperlukan untuk bahan analisa korelasi yang akan dibahas pada bab selanjutnya.

Sebagai main test, peneliti akan menguji korelasi yang ada antara kedua variabel. Uji korelasi dilakukan apabila ada minimal dua variabel yang diasumsikan memiliki hubungan, namun tidak dapat ditentukan variabel mana yang menjadi sebab dan akibat. Karena data berskala ordinal, maka uji korelasi ini menggunakan Pearson Correlation apabila data berdistribusi normal dan Spearman Rho Correlation apabila data tidak berdistribusi normal. Maka sebelum uji ini dilakukan, peneliti akan menguji normalitas data terlebih dahulu.

Sebagai langkah awal, peneliti memberi coding manual pada lembar kuesioner yang sudah diterima. Lantas defining variabel dilakukan berdasarkan gender, usia, nama sekolah dan butir pertanyaan pada setiap variabel. Kemudian, 378 data dan jawaban kuesioner dimasukkan berdasarkan coding awal yang telah disusun. Pada akhirnya, peneliti menjumlahkan total nilai dari butir pertanyaan berdasarkan variabel untuk dilakukan uji selanjutnya. Untuk menjawab rumusan masalah (uji hipotesis) dilakukan uji korelasi (untuk hipotesis pertama) dan uji beda 
(untuk menjawab hipotesis kedua dan ketiga). Dalam proses pengolahan data ini, peneliti menggunakan aplikasi SPSS sebagai alat pengolahan data.

\section{Dimensi dan Indikator}

Dalam penelitian ini, dimensi dan indikator yang akan diteliti dalam setiap variabel adalah variabel $(\mathrm{X})$ literasi digital dan $(\mathrm{Y})$ pembukaan diri di sosial media. Dalam variabel literasi digital, ada tujuh elemen yang akan digunakan untuk mengukur tingkatan literasi digital pelajar remaja di Kecamatan Medan Kota, diantaranya:

\section{(1) Literasi Informasi}

Literasi informasi adalah kemampuan pengguna media digital untuk menemukan, menafsirkan, mengevaluasi, mengelola, hingga membagikan informasinya melalui akun sosial media yang mereka kelola untuk dikonsumsi publik.

(2) Digital Scholarship

Digital Scholarship adalah elemen yang mencakup partisipasi aktif pengguna media digital dalam kegiatan akademik untuk menjadikan informasi dari media digital tersebut sebagai referensi data, misalnya pada praktek penelitian atau penyelesaian tugas sekolah.

(3) Learning Skills

Learning Skills adalah keterampilan para pengguna media digital untuk bisa menggunakan teknologi untuk mendukung aspek kehidupannya seperti proses belajar mengajar, kerja sama tim (team work) untuk meningkatkan performa.

(4) ICT Literacy

ICT Literacy fokus pada kemampuan pengguna media digital untuk mengadopsi, menyesuaikan dan menggunakan perangkat digital baik aplikasi dan layanannya, serta persepsi pengguna terhadap teknologi yang dapat memajukan kehidupan.

(5) Manajemen Privasi

Elemen ini lebih memfokuskan bagaimana pengguna media digital mengelola identitas online. Termasuk di dalamnya penggunaan password untuk keamanan data, blocking terhadap akun yang tidak diharapkan, filter saat menerima permintaan pertemanan. Kemampuan pengguna media digital untuk mengaktivasi fitur-fitur yang dimiliki oleh setiap aplikasi dapat menjaga kerahasian informasi yang dibagikan oleh pengguna .

(6) Communication and Collaboration

Dimensi ini terkait dengan partisipasi aktif pengguna media digital untuk mengefisiensikan waktu. Hal ini erat kaitannya dengan media sebagai digital, yang memiliki konvergensi, seperti mengaktifkan koneksi antara akun instagram dengan 
facebook untuk mengirimkan informasi yang tentunya akan menghemat waktu pengguna itu sendiri.

(7) Media Literacy

Literasi media adalah kemampuan pengguna media digital yang secara kritis dan kreatif dapat menyaring informasi yang beredar di berbagai media. Hal ini dapat dicontohkan dengan tidak mencari berita dari satu sumber saja, melainkan mencari sumber berita lain sebagai perbandingan untuk mengukur akurasi data.

2. Variabel Pembukaan Diri mencakup lima dimensi untuk mengukur tingkatan pembukaan diri pelajar remaja di Kota Medan, diantaranya:

(1) Depth/intimacy (kedalaman)

Merupakan dimensi yang menunjukan sifat intim yang dikandung dalam suatu informasi yang diungkapkan oleh individu.

(2) Honesty (kejujuran dan kecermatan)

Merupakan dimensi yang menunjukan ketepatan dan kejujuran individu dalam mengungkapkan diri.

(3) Amount (ukuran)

Merupakan dimensi yang menunjukan kuantitas dari pembukaan diri, dapat diukur dengan mengetahui frekuensi kepada siapa individu mengungkapkan diri dan durasi dari pesan yang disampaikan atau waktu yang diperlukan untuk mengutarakan pesan tersebut.

(4) Valency (valensi)

Merupakan dimensi yang menjelaskan mengenai hal-hal yang positif dan negatif dari perilaku pembukaan diri, dimana individu dapat menunjukan perilaku mengenai hal-hal yang menyenangkan atau tidak menyenangkan mengenai dirinya, memuji hal-hal yang ada dalam dirinya atau menjelek-jelekan diri individu sendiri.

(5) Intention (tujuan)

Merupakan dimensi yang menjelaskan seluas apa individu mengungkapkan tentang apa yang ingin diungkapkan, seberapa besar kesadaran individu untuk mengontrol informasi-informasi yang akan dikatakan pada orang lain.

\section{Skala Pengukuran}

Dalam penelitian ini digunakan alat ukur berbentuk kuesioner dimana alat ukur pertama digunakan untuk melihat tingkatan literasi digital dan alat ukur kedua untuk melihat tingkatan pembukaan diri di media sosial pada pelajar remaja di Kecamatan Medan Kota. 
Alat ukur pertama disusun berdasarkan ketujuh elemen yang terangkum dalam konsep literasi digital dengan total 17 butir pertanyaan. Butir pertanyaan 1-3 mewakili dimensi informasi dan media literasi, butir pertanyaan 4-5 mewakili dimensi digital scholarsibip, butir pertanyaan 6-8 mewakili dimensi keterampilan belajar, butir pertanyaan 9-11 mewakili dimensi ICT Literacy, butir pertanyaan 12-15 mewakili dimensi pengaturan privasi dan terakhir butir pertanyaan 1617 mewakili dimensi komunikasi dan kolaborasi. Skala pengukuran yang digunakan adalah skala Likert (ordinal) dengan angka 1-4 dengan artian sangat setuju (1), setuju (2), kurang setuju (3), tidak setuju (4). Setiap item yang ada akan diberi skor 1-4 sesuai dengan jawaban yang dipilih oleh responden pada form kuesioner.

Alat ukur kedua diadaptasi dari kuesioner Revised Self Disclosure Scale RSDS dikembangkan oleh Blau (2011) ${ }^{17}$. Dalam penelitiannya, Blau mengadaptasi alat ukur ini dari penelitian desertasi Leung $^{18}$ yang berjudul "Depth, Honesty and Intention" tahun 2002 diterbitkan oleh Mary Ann Liebert, Inc. Kuesioner ini berbahasa asli bahasa Inggris. Peneliti melakukan proses back translation, sesuai dengan prosedur dari Brislin, R.W (1970) ${ }^{19}$ yang dilakukan dengan menterjemahkan dari bahasa asli kuesioner ke bahasa Indonesia yang dilakukan oleh penerjemah lokal, dan kemudian hasil dari terjemahan tersebut diterjemahkan kembali ke bahasa asli oleh ahli bahasa untuk melakukan pengecekan apakah ditemukan perbedaan makna atau tidak.

Dalam kuesioner variabel ini, ada 17 butir pertanyaan yang mewakili kelima dimensi pada variabel Self Disclosure Online ini, diantaranya butir pertanyaan 1-5 mewakili dimensi ukuran, butir pertanyaan 6-8 mewakili dimensi valensi keterbukaan diri, butir pertanyaan 9-11 mewakili dimensi kejujuran, butir pertanyaan no 12-15 mewakili dimensi maksud dan tujuan, dan terakhir butir pertanyaan 16-17 mewakili dimensi terakhir yaitu intimasi.

\section{Populasi dan Sampling}

Peneliti menentukan populasi penelitian ini adalah pelajar remaja di sekolah - sekolah pada Kecamatan Medan Kota karaena kecamatan ini menempati posisi teratas dalam jumlah SMA di Kota Medan dengan jumlah 20 sekolah (4 SMA negeri dan 16 SMA swasta) sesuai dengan data dari Dinas Pendidikan Kota Medan (2017). Dilihat dari penentuan sumber data, populasi dalam penelitian ini termasuk dalam populasi terbatas, yaitu populasi yang memiliki sumber data yang jelas batas-batasnya secara kuantitatif.

\footnotetext{
17 Blau, I. (2011). Application Use, Online Relationship Type,Self-disclosure, And the Internet Abuse Among Children and Youth: Implications for Educational and Safety Programs. Journal Educational and Computing Research, 45(1), 95-116.

${ }^{18}$ Leung,L. (2002). Loneliness, Self-Disclosure, and ICQ ("I Seek You”) Use. CyberPsychology and Behavior : Mary Ann Liebert, Inc.

${ }^{19}$ Brislin, R.W. (1970). "Back-Translation for Cross-Cultural Research”. Journal of Cross-Cultural Psychology. Sage Journals.
} 


\section{Stella Stefany, Nurbani, Badarrudin}

Peneliti menggunakan teknik purposive sampling pada penelitian ini. Menurut Masri Singarimbun dan Sofian Effendi (2002:115) ${ }^{20}$ Purposive Sampling yaitu mengambil sampel secara sengaja dari keseluruhan populasi yang telah diidentifikasi karakteristiknya. Teknik sampling ini menuntut bahwasannya secara ideal peneliti telah mengetahui besaran populasi induk (pelajar remaja di Kota Medan) dan peneliti bersikap bahwa setiap unsur atau kelompok unsur harus memiliki peluang yang sama untuk dijadikan sampel. Data yang diperoleh dari BPS tentang jumlah SMA di kota Medan berdasarkan Kecamatan dapat dilihat pada Tabel 1.

Tabel 1. Daftar Jumlah SMA di Kota Medan Berdasarkan Kecamatan

\begin{tabular}{|c|c|c|c|c|}
\hline \multirow{2}{*}{ No } & \multirow{2}{*}{ Kecamatan } & \multicolumn{2}{|c|}{ SMA } & \multirow{2}{*}{ Tota } \\
\hline & & Negeri & Swasta & \\
\hline 1 & Medan Tuntungan & 1 & 6 & 7 \\
\hline 2 & Medan Johor & 1 & 16 & 17 \\
\hline 3 & Medan Amplas & 0 & 7 & 7 \\
\hline 4 & Medan Denai & 2 & 11 & 13 \\
\hline 5 & Medan Area & 1 & 8 & 9 \\
\hline 6 & Medan Kota & 4 & 17 & 21 \\
\hline 7 & Medan Maimun & 0 & 5 & 5 \\
\hline 8 & Medan Polonia & 2 & 6 & 8 \\
\hline 9 & Medan Baru & 0 & 10 & 10 \\
\hline 10 & Medan Selayang & 0 & 7 & 7 \\
\hline 11 & Medan Sunggal & 1 & 11 & 12 \\
\hline 12 & Medan Helvetia & 1 & 18 & 19 \\
\hline 13 & Medan Petisah & 1 & 9 & 10 \\
\hline 14 & Medan Barat & 1 & 8 & 9 \\
\hline 15 & Medan Timur & 1 & 10 & 11 \\
\hline 16 & Medan Perjuangan & 0 & 7 & 7 \\
\hline 17 & Medan Tembung & 1 & 13 & 14 \\
\hline 18 & Medan Deli & 0 & 5 & 5 \\
\hline 19 & Medan Labuhan & 2 & 2 & 4 \\
\hline 20 & Medan Marelan & 1 & 7 & 8 \\
\hline 21 & Medan Belawan & 1 & 3 & 4 \\
\hline
\end{tabular}

Dari data pada Tabel 1, peneliti menentukan populasi penelitian ini adalah pelajar remaja di sekolah - sekolah pada Kecamatan Medan Kota yang menempati posisi teratas dalam jumlah SMA di Kota Medan dengan jumlah 21 sekolah (4 SMA negeri dan 17 SMA swasta). Data BPS tersebut diatas merupakan data tahun 2016 yang dibukukan pada awal tahun 2017.

${ }^{20}$ Singarimbun, Masri dan Sofian Effendi. (2008). Metode Penelitian Survei, Jakarta: LP3ES. 
Berdasarkan update dari Dinas Pendidikan Kota Medan (Jl.Pelita), data SMA yang ada di Kecamatan Medan Kota per tahun ajaran baru (Juli 2017) mengalami penyesuaian pada Tabel 2.

Tabel 2. Daftar Sekolah dan Jumlah Siswa SMA Kecamatan Medan Kota

\begin{tabular}{clcc}
\hline \hline No & \multicolumn{1}{c}{ Nama Sekolah } & $\begin{array}{c}\text { Jumlah } \\
\text { Siswa }\end{array}$ & Presentase \\
\hline 1 & SMAS Methodist 2 Medan & 1820 & $24.60 \%$ \\
\hline 2 & SMAS Tunas Gajah Mada & 132 & $1.78 \%$ \\
\hline 3 & SMAS UISU Medan & 139 & $1.88 \%$ \\
\hline 4 & SMAN 5 Medan & 743 & $10.04 \%$ \\
\hline 5 & SMAS Dwiwarna & 20 & $0.27 \%$ \\
\hline 6 & SMAS Al Ittihadiyah & 105 & $1.42 \%$ \\
\hline 7 & SMAS Indonesia Membangun & 113 & $1.53 \%$ \\
\hline 8 & SMAS Parulian 1 & 119 & $1.61 \%$ \\
\hline 9 & SMAS WR Supratman 1 & 129 & $1.74 \%$ \\
\hline 10 & SMAS Wiyata Dharma & 148 & $2.00 \%$ \\
\hline 11 & SMAS Widiasana Utama & 39 & $0.53 \%$ \\
\hline 12 & SMAS Nasrani 3 Medan & 40 & $0.54 \%$ \\
\hline 13 & SMAN 18 Medan & 328 & $4.43 \%$ \\
\hline 14 & SMAS YPK Medan & 331 & $4.47 \%$ \\
\hline 15 & SMAN 10 Medan & 442 & $5.97 \%$ \\
\hline 16 & SMAS ERIA Medan & 463 & $6.26 \%$ \\
\hline 17 & SMAN 6 Medan & 472 & $6.38 \%$ \\
\hline 18 & SMAS Sutomo 1 & 1663 & $22.48 \%$ \\
\hline 19 & SMAS Hang Kesturi & 72 & $0.97 \%$ \\
\hline 20 & SMAS Advent Air Bersih Medan & 81 & $1.09 \%$ \\
\hline & & 7399 & $100.00 \%$ \\
\hline Total & S Dins Pendikn Kota Medn $\% 17 \%$ & \\
\hline
\end{tabular}

Sumber : Dinas Pendidikan Kota Medan (Juli 2017)

Sebagai tahap pertama, peneliti menghitung besaran sampel yang harus ditarik dari populasi yang berjumlah 7.399 siswa tersebut. Besaran sampel yang akan digunakan dalam penelitian ini akan menggunakan perhitungan dari tabel Taro Yamane $(1967)^{21}$.

Dengan tingkat presisi $\pm 5 \%$ peneliti menyebarkan 378 kuesioner yang tersebar secara proporsional pada sekolah - sekolah baik negeri maupun swasta di Kecamatan Medan Kota. Proporsional diartikan dalam perhitungan jumlah siswa sekolah tertentu dibagi jumlah keseluruhan siswa di Kecamatan Medan Kota dikalikan 100\%. Hasil dari perhitungan diatas dikalikan jumlah sampel yang akan digunakan. Hasil dari perhitungan tersebut dirangkum dalam Tabel 3.

${ }^{21}$ Yamane, T. (1967). Statistics, An Introductory Analysis, $2^{\text {nd }}$ Ed. New York: Harper and Row. 
Tabel 3. Distribusi Proposional Sampling

\begin{tabular}{clccc}
\hline \hline No & Nama Sekolah & $\begin{array}{c}\text { Jumlah } \\
\text { Siswa }\end{array}$ & Presentase & $5 \%$ \\
\hline 1 & SMAS Methodist 2 Medan & 1820 & $24.60 \%$ & 93 \\
\hline 2 & SMAS Tunas Gajah Mada & 132 & $1.78 \%$ & 7 \\
\hline 3 & SMAS Uisu Medan & 139 & $1.88 \%$ & 7 \\
\hline 4 & SMAS 5 Medan & 743 & $10.04 \%$ & 38 \\
\hline 5 & SMAS Dwiwarna & 20 & $0.27 \%$ & 1 \\
\hline 6 & SMAS Al Ittihadiyah & 105 & $1.42 \%$ & 5 \\
\hline 7 & SMAS Indonesia Membangun & 113 & $1.53 \%$ & 6 \\
\hline 8 & SMAS Parulian 1 & 119 & $1.61 \%$ & 6 \\
\hline 9 & SMAS Wr Supratman 1 & 129 & $1.74 \%$ & 7 \\
\hline 10 & SMAS Wiyata Dharma & 148 & $2.00 \%$ & 8 \\
\hline 11 & SMAS Widiasana Utama & 39 & $0.53 \%$ & 2 \\
\hline 12 & SMAS Nasrani 3 Medan & 40 & $0.54 \%$ & 2 \\
\hline 13 & SMAS 18 Medan & 328 & $4.43 \%$ & 17 \\
\hline 14 & SMAS Ypk Medan & 331 & $4.47 \%$ & 17 \\
\hline 15 & SMAS 10 Medan & 442 & $5.97 \%$ & 23 \\
\hline 16 & SMAS Eria Medan & 463 & $6.26 \%$ & 24 \\
\hline 17 & SMAS 6 Medan & 472 & $6.38 \%$ & 24 \\
\hline 18 & SMAS Sutomo 1 & 1663 & $22.48 \%$ & 85 \\
\hline 19 & SMAS Hang Kesturi & 72 & $0.97 \%$ & 4 \\
\hline 20 & SMAS Advent Air Bersih Medan & 81 & $1.09 \%$ & 4 \\
\hline & & 7399 & $100.00 \%$ & 378 \\
\hline Total & $:$ Dinas Pendidin Ko Medan 0412017$)$ & & \\
\hline
\end{tabular}

Sumber : Dinas Pendidikan Kota Medan (Juli 2017)

\section{KERANGKA KONSEP/TEORITIS}

\section{Teori Manajemen Privasi Komunikasi (CPM)}

Petronio (2016) 22 Teori Manajemen Privasi Komunikasi (Communication Privacy Management CPM) menunjukkan bahwa individu mempertahankan dan mengkoordinasikan privasi batas (batas-batas dari apa yang mereka bersedia untuk berbagi) dengan berbagai mitra komunikasi tergantung pada manfaat yang dirasakan dan biaya pengungkapan informasi. Teori yang dikembangkan oleh Sandra Petronio ini menggunakan batas metafora untuk menjelaskan privasi dalam proses manajemen, privasi batas-batas yang menarik perpecahan antara informasi pribadi dan informasi publik. Teori ini berpendapat bahwa ketika orang-orang mengungkapkan informasi pribadi, mereka bergantung pada aturan manajemen berbasis sistem untuk mengontrol tingkat aksesibilitas. Privasi individu mengatur batasnya pengungkapan diri. Setelah pengungkapan dibuat, negosiasi aturan privasi antara kedua belah pihak diperlukan.

22 Petronio, S. (2016). The International Encyclopedia of Communication Theory and Philosophy. London, UK: Wiley-Blackwell.

20 | SLSIOGLLBAL : Jurnal Pemikiran dan Penelitian Sasiolagi, Val. 2, №. I, Desember 2017 
CPM adalah teori praktis didesain untuk menjelaskan isu-isu "keseharian" seperti yang digambarkan dalam kegiatan kita sehari-hari. Ketika kita bertemu dengan berbagai macam orang dalam kehidupan - rekan sekerja, teman sekelas, anggota keluarga, teman sekamar, dan seterusnya - kita terlibat di dalam negosiasi kompleks antara privasi dan keterbukaan. Memutuskan apa yang akan diungkapkan dan apa yang harus dirahasiakan bukanlah keputusan yang dapat langsung diambil, melainkan merupakan tindakan penyeimbangan yang berlangsung secara terus-menerus.

Kita berusaha untuk menimbang tuntutan-tuntutan situasi dengan kebutuhan kita dan orang lain yang ada disekitar kita. Privasi merupakan hal yang penting bagi kita karena hal ini memungkinkan kita untuk merasa terpisah dari orang lain. Hal ini memberikan kita perasaan bahwa kita adalah pemilik sah dari informasi mengenai diri kita. Ada risiko yang dapat muncul dari pembukaan kepada orang yang salah, membuka diri pada saat yang tidak tepat, mengatakan terlalu banyak tentang diri kita sendiri, atau berkompromi dengan orang lain. Di lain pihak, pembukaan dapat memberikan keuntungan yang besar, kita dapat meningkatkan kontrol sosial, memvalidasi perspektif kita, dan menjadi lebih intim dengan mitra komunikasi dalam suatu hubungan ketika kita membuka diri. Keseimbangan antara privasi dan keterbukaan memiliki makna karena hal ini sangat penting terhadap cara kita mengelola hubungan-hubungan kita.

Munculnya teori manajemen privasi komunikasi ini menarik karena tiga alasan. Yang pertama, teori ini adalah pemikiran yang terkini dalam disiplin ilmu komunikasi. Munculnya teori baru memberikan gambaran akan hidupnya komunikasi sebagai bidang ilmu. Kedua, fakta bahwa CPM bertumbuh secara khusus dari fokus terhadap komunikasi. Ini bukti akan kematangan dan pertumbuhan bidang ilmu komunikasi (Baxter \& Braithwaite, 2008) ${ }^{23}$.

Dalam ensiklopedia yang ditulis oleh Petronio (2016) dengan judul Communication Privacy Management dalam The International Encyclopedia of Communication Theory and Philosophy menjelaskan latar belakang munculnya teori CPM ini. Diawali dari penelitian pertama Petronio dan koleganya pada tahun 1984 dengan judul penelitian Prerequisite Conditions For Self-Disclosing: A Gender Issue ${ }^{24}$ dan tahun 1986 dengan judul Ramifications of Revealing Private Information: A Gender Gap ${ }^{25}$ yang menggambarkan prinsip-prinsip yang kemudian akan menjadi bagian dari

\footnotetext{
${ }^{23}$ Baxter, L.A. \& Braithwaite, D.O. (2008) Engaging Theories in Interpersonal Communication: Multiple Perspectives. New York: Sage Publication, Inc.

24 Petronio, S., Martin, J., Littlefield, R. (1984). Prerequisite conditions for self-disclosing: A gender issue. Communication Monographs 51 (3), 268-273

25 Petronio, S. \& Martin, J.N. (1986). Ramifications of revealing private information: A gender gap. Journal of Clinical Psychology 42 (3), 499-506
} 
Stella Stefany, Nurbani, Badarrudin

teori CPM. Dalam penelitian-penelitian ini para peneliti tertarik akan kriteria dalam pembentukan aturan dalam sistem manajemen aturan bagi pembukaan. Mereka mengamati bahwa pria dan wanita memiliki kriteria yang berbeda untuk menilai kapan harus terbuka dan kapan harus diam.

Pada tahun 1991, Petronio menerbitkan usaha pertamanya untuk mengorganisasikan semua prinsip-prinsip dari teori ini. Karyanya ini kemudian berbeda dengan konseptualisasinya yang muncul belakangan dalam dua hal. Yang pertama, teori yang memiliki batasan yang lebih sempit di tahun 1991. Pada saat itu, Petronio menyebut hal ini sebagai mikro teori karena batasannya hanya sampai pada manajemen privasi pada pasangan yang menikah. Sekarang Petronio menyebut CPM sebagai makroteori karena sekarang batasannya melingkupi berbagai macam hubungan yang lebih luas termasuk dalam kelompok dan organisasi.

Perubahan kedua ini adalah perubahan nama. Di tahun 1991, Petronio menyebut teori ini Teori Batasan Komunikasi (Communication Boundary Management). Ia menerbitkan karyanya yang lebih lengkap mengenai teori ini dalam bukunya pada tahun 2002, beliau memberikan nama Teori Manajemen Privasi Komunikasi (Communication Privacy Management Theory). Petronio menjelaskan bahwa nama baru lebih merefleksikan fokus terhadap pembukaan pribadi.

Teori manajemen privasi komunikasi berakar pada asumsi-asumsi mengenai bagaimana seorang individu berpikir dan berkomunikasi sekaligus asumsi-asumsi mengenai sifat dasar manusia. Yang pertama, CPM menganut aspek-aspek peraturan dan sistem metateori. Dengan adanya dasar metateoritis ini, muncul lima asumsi mengenai sifat dasar manusia:

1) Manusia adalah pembuat keputusan

2) Manusia adalah pembuat peraturan dan pengikut peraturan

3) Pilihan dan peraturan manusia didasarkan pada pertimbangan akan orang lain dan juga konsep diri.

4) Hidup berhubungan dicirikan oleh perubahan.

5) Kontradiksi adalah fakta mendasar pada hidup berhubungan.

Menurut Petronio, "manusia membuat pilihan dan peraturan mengenai apa yang harus dikatakan dan apa yang harus disimpan dari orang lain yang didasarkan pada kriteria penting di antaranya seperti budaya, gender, dan konteks". Teori CPM ini merupakan teori yang mendukung asumsi yang dimiliki teori dialektika relasional, yaitu mendefinisikan pola komunikasi antara mitra hubungan sebagai akibat dari ketegangan dialektis endemik. 
Teori Manajemen privasi komunikasi (CPM) tertarik untuk menjelaskan proses-proses negosiasi orang seputar pembukaan informasi privat. Teori ini tidak membatasi proses ini hanya kepada diri, tetapi memperluas mencakup banyak level pembukaan termasuk kelompok dan organisasi. Untuk mencapai tujuan ini, teori CPM mengajukan lima asumsi dasar: informasi privat, batasan privat, kontrol dan kepemilikan, sistem manajemen berdasarkan aturan, dan dialektika manajemen.

Ada lima asumsi yang digunakan dalam teori CPM ini, diantaranya : (1) Informasi Privat. Asumsi yang pertama, informasi privat merujuk pada cara tradisional untuk berpikir mengenai pembukaan. Ini merupakan informasi mengenai hal-hal yang sangat berarti bagi seseorang yang sifatnya privat. Isi dari pembukaan memungkinkan kita untuk menguraikan konsepkonsep mengenai privasi dan keintiman dan mempelajari bagaimana mereka saling berhubungan. Keintiman adalah perasaan atau keadaan seseorang secara mendalam dalam cara-cara fisik, psikologi, emosional, dan perilaku karena orang ini penting dalam kehidupan seseorang. Keintiman adalah keadaan merasa mengetahui seseorang secara mendalam dalam segala hal karena orang ini penting didalam kehidupan seseorang. (2) Batasan Privat (private boundary). CPM bergantung pada metafora batasan untuk menjelaskan bahwa terdapat garis antara bersikap publik dan bersikap privat. Ketika informasi privat dibagikan batasan disekelilingnya disebut batasan kolektif (collective boundary), dan informasi itu tidak hanya mengenai diri; informasi ini menjadi milik hubungan yang ada. Ketika informasi privat tetap disimpan oleh seorang individu dan tidak dibuka, maka batasannya disebut batasan personal (personal boundary). (3) Kontrol dan Kepemilikan. Asumsi ini bergantung pada ide bahwa orang merasa mereka memiliki informasi privat mengenai diri mereka sendiri. Sebagai pemilik informasi ini, mereka percaya bahwa mereka harus ada dalam posisi untuk mengontrol siapa saja (jika memang ada) yang boleh mengakses informasi ini. (4) Sistem Manajemen Berdasarkan Aturan. Sistem ini adalah kerangka untuk memahami keputusan yang dibuat orang mengenai informasi privat. Sistem manajemen berdasarkan aturan memungkinkan pengelolaan pada level individual dan kolektif serta merupakan pengaturan rumit yang terdiri atas tiga proses: (i) Karakteristik aturan privasi adalah salah satu proses di dalam sistem manajemen aturan privasi, yang mendeskripsikan sifat dasar dari aturan privasi. Karakteristik ini memiliki dua fitur utama yaitu pengembangan aturan dan atribut. (ii) Koordinasi batasan, merujuk pada bagaimana kita mengelola informasi yang dimiliki bersama. Pertalian batasan (boundary linkage) merujuk pada hubungan yang membentuk aliansi batasan antar individu. Kepemilikan batasan (boundary ownership) merujuk pada hak-hak dan keistimewaan yang diberikan kepada pemilik pendamping (co-owner) dari sebuah informasi privat. Terakhir 
koordinasi batasan dicapai melalui permeabilitas batasan (boundary permeability) yang merujuk pada seberapa banyak informasi dapat melalui batasan yang ada. Ketika akses terhadap suatu informasi privat ditutup, batasannya disebut sebagai batasan tebal (batasan tertutup yang memungkinkan sedikit atau tidak ada informasi yang dapat lewat, sedangkan ketika aksesnya terbuka, batasannya disebut sebagai batasan tipis (batasan terbuka yang memungkinkan semua informasi lewat). (iii) Turbulensi batasan, (boundary turbulence) muncul ketika aturan-aturan koordinasi batasan tidak jelas atau ketika harapan orang untuk manajemen privasi berkonflik antara satu dengan yang lainnya. Kasus yang mungkin dalam turbulensi batasan adalah bocornya suatu rahasia seseorang atau organisasi ke pihak atau orang lain. Dan asumsi terakhir (5) Dialektika Manajemen. Asumsi yang kelima, dialektika manajemen privasi, berfokus pada ketegangan-ketegangan antara keinginan untuk mengungkapkan informasi privat dan keinginan untuk menutupinya. Pandangan dasar dari teori ini didasarkan pada kesatuan dialektika, yang merujuk pada ketegangan-ketegangan yang dialami oleh orang sebagai akibat dari oposisi dan kontradiksi.

Pada akhirnya, peneliti memilih teori CPM sebagai dasar teoritis untuk menguji hubungan antara pemahaman pengguna media sosial akan literasi digital (manfaat dan biaya (yang dimaksud dengan biaya disini adalah hal-hal yang menjadi "harga yang harus dibayar")) dan hubungannya dengan self disclosure online (keterbukaan privasi pengguna).

\section{PEMBAHASAN}

Sebagai langkah awal, peneliti melakukan uji reliabilitas dan validitas terhadap kuesioner. Hasil dari uji reliabilitas variabel literasi digital dapat dilihat pada Tabel 5.

Tabel 5. Uji Reliabilitas Literasi Digital

\begin{tabular}{cc}
\hline Cronbach's Alpha & N of Items \\
\hline 0.658 & 17 \\
\hline Sumber: Pengolahan Data Kuesioner (2017)
\end{tabular}

Setelah uji reliabilitas dilakukan, peneliti melanjutkan dengan uji validitas. Peneliti harus mengeliminasi butir-butir pertanyaan dari nilai terendah satu per satu dengan nilai Corrected Item-Total Correlation minimal 0.2 untuk mendapatkan hasil dari uji reliabilitas yang valid. Setelah mengeliminasi masing-masing butir pertanyaan yang nilainya di bawah batas nilai minimum, yaitu X2, X6, X14, X15, X16, X18, X21 dan X25, peneliti mendapatkan 17 pertanyaan yang dinyatakan valid untuk diuji pada penelitian ini. Sementara itu, hasil uji reliablitias variabel Y (Pembukaan Diri) dirangkum dalam Tabel 6. 
Tabel 6. Uji Reliabilitas Variabel Pembukaan Diri

\begin{tabular}{cc}
\hline \hline Cronbach's Alpha & N of Items \\
\hline 0.669 & 15 \\
\hline
\end{tabular}

Sumber: Pengolahan Data Kuesioner (2017)

Setelah mengeliminasi 2 butir pertanyaan satu per satu mulai dari nilai terendah, pada akhirnya peneliti mendapatkan mendapatkan nilai standar Cronbach's Alpha untuk menyatakan butir pertanyaan tersebut valid untuk digunakan. Minimal nilai validitas butir yang disarankan adalah 0.2, sedangkan nilai minimal reliabilitas dimensi atau alat ukur yang disarankan adalah 0.6. Dalam hal ini, rangkuman nilai reliabilitas Cronbach's Alpha variabel X adalah sebesar 0.658 dan variabel Y sebesar 0,669. Dan pada kolom corrected item-total correlation butir pertanyaan yang terangkum dalam kuesioner sudah memenuhi nilai minimal yaitu 0.2 .

Sebelum melakukan perhitungan lebih jauh, peneliti melakukan tes normalitas data sebagai acuan untuk metode yang akan digunakan pada uji berikutnya. Hasil dari uji normalitas ini menunjukkan data tidak terdistribusi dengan normal, seperti yang tergambar pada Gambar 1.

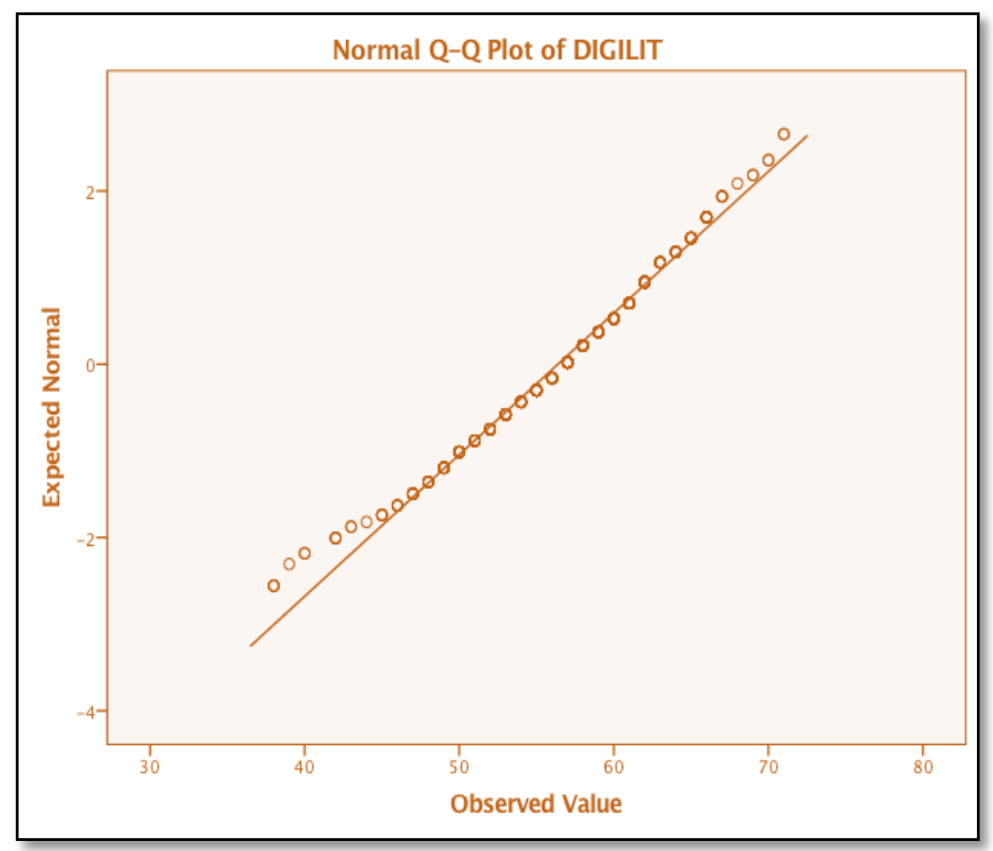

Gambar 1. Hasil Uji Normalitas Data

Data dapat dikatakan berdisitribusi normal jika nilai Sig. (p) pada maupun Shapiro-Wilk $>0.05$. Dalam hal ini, data variabel literasi digital mendapat nilai 0.01 dan variabel pembukaan diri mendapat nilai 0.03 dan data kedua variabel bisa dikategorikan berdisitribusi tidak normal. Untuk itu, uji hipotesis mengenai korelasi kedua variabel yang akan digunakan hanya bisa dilakukan dengan menggunakan pendekatan Spearman Rank. Hasil uji korelasi dari variabel X dan Y disajikan pada Tabel 7. 
Tabel 7. Hasil Uji Korelasi Spearman

\begin{tabular}{lccc}
\hline & & DIGILIT & SDO \\
\hline DIGILIT & Correlation Coefficient & 1 & $.508^{* *}$ \\
\hline SDO & Correlation Coefficient & $.508^{* *}$ & 1 \\
\hline \multirow{2}{*}{ ** Correlation is significant at the 0.01 level (2-tailed). } \\
\multicolumn{4}{l}{ Sumber: Pengolahan Data Kuesioner (2017) }
\end{tabular}

Dari Tabel 7 dapat diketahui bahwa nilai korelasi antara variabel literasi digital dengan variabel pembukaan diri pelajar remaja di Kecamatan Medan Kota mendapat skor 0.508 yang artinya nilai positif. Nilai positif ditafsirkan sebagai hubungan linear antara kedua variabel. Berdasarkan skala Guilford, besaran nilai hasil uji korelasi antara Variabel (x) terhadap (y) sebesar $0.508^{* *}$ diinterpretasikan dengan kekuatan hubungan yang sedang diantara kedua variabel. Nilai $0.508^{* *}$ menunjukkan bahwa hubungan antara $\mathrm{x}$ dan y signifikan pada level 0.01 (99\% signifikan) yang berarti hipotesis yang adanya korelasi $\mathrm{x}$ dan y diterima.

\section{PEMBAHASAN}

Hasil penelitian menunjukkan adanya korelasi positif antara variabel X dan Y (dalam penelitian ini: literasi digital dan pembukaan diri di media sosial pada pelajar remaja) dengan nilai 0.508 $(\mathrm{n}=378)$. Hubungan dari angka tersebut menunjukkan keterkaitan yang sedang berdasarkan koefisien Guilford. Nilai ini diperoleh dari hasil uji korelasi Spearman atas 17 butir pertanyaan pada setiap variabel dengan total 34 butir pertanyaan. Keterkaitan antara kedua variabel diasumsikan karena sifat dasar pengguna (pelajar remaja) seperti yang dikemukakan oleh Hurlock (2011) yang menyatakan masa remaja (dalam bahasa asli: adolescence) adalah masa transisi (peralihan) yang menyangkut kematangan mental, emosional, sosial dan fisik. Pada masa remaja ini, mereka tidak memiliki tempat yang jelas karena tidak termasuk dalam golongan anak, golongan dewasa maupun golongan tua. Masa transisi dianggap sebagai masa pencarian, belum ada stabilitas yang bisa muncul ketika pencarian belum menemukan hasil.

Leung (2006) dalam penelitian terdahulu menyatakan dalam kehidupan informasi yang berlimpah, pengguna seringkali tanpa disadari memiliki maksud dan tujuan menjadikan gawai sebagai 'obat' untuk memperbaiki mood dan 'alat' untuk menunjang eksistensi diri. Maksud dan tujuan dari penggunaan media sosial yang dinyatakan oleh responden diantaranya adalah keinginan untuk dikagumi dinyatakan dengan sangat setuju dan setuju oleh 158 responden (41.8\%) sementara 220 responden (58.2\%) menyatakan kurang setuju dan tidak setuju. Maksud dan tujuan untuk mendapatkan respon dari pembukaan diri dinyatakan sangat setuju dan setuju oleh sebanyak 206 responden (54.5\%) dan 172 responden (45.5\%) menyatakan 
kurang setuju dan tidak setuju. Keinginan untuk disukai (likes) dinyatakan sangat setuju dan setuju oleh 227 responden (60.1\%) dan 151 responden (39.9\%) menyatakan kurang dan tidak setuju.

Dengan maksud dan tujuan di atas, responden pelajar remaja yang ingin membuka informasi tentang dirinya harus memiliki keterampilan dalam menggunakan perangkat maupun aplikasi media sosial yang terdapat di dalam gawai yang mereka miliki. Media sosial didefinisikan sebagai suatu layanan berbasis web yang memungkinkan setiap individu untuk membangun hubungan sosial melalui dunia maya seperti membangun suatu profil tentang dirinya sendiri, menunjukkan koneksi seseorang dan memperlihatkan hubungan apa saja yang ada antara satu pengguna dengan pengguna lainnya dalam sistem yang disediakan (Boyd dan Ellison, 2007).

Keterampilan responden dalam menggunakan perangkat teknologi informasi (ICT literasi) ini didapati baik pada 262 responden (69.4\%) dan kurang baik pada 116 responden (30.6\%). 113 responden (29.9\%) menyatakan sangat setuju dan 214 responden (56.6\%) menyatakan setuju terhadap pernyataan "Saya tidak mengalami kesulitan dalam mempelajari teknologi baru". Sementara itu, 127 responden (33.6\%) menyatakan sangat setuju dan 200 responden $(52.9 \%)$ menyatakan setuju terhadap pernyataan "Belajar tentang teknologi akan menolong saya memiliki kehidupan yang lebih baik". Poin terakhir dari aspek ICT literasi didapati 278 responden $(73.6 \%)$ menyatakan percaya diri dalam mempelajari teknologi, sementara itu 100 responden $(26.4 \%)$ menyatakan kurang percaya diri dalam mempelajari teknologi.

Temuan dari aspek ICT literasi menjadi serupa dengan penelitian terdahulu yang dilakukan oleh Oyedemi (2014). Penelitian terdahulu menyatakan 59.4\% responden (remaja di Afrika Selatan) sangat percaya diri dalam menggunakan teknologi, sementara 34.6\% lainnya menyatakan tidak percaya diri dalam menggunakan teknologi. Dalam hal ini, faktor perbedaan budaya antara responden di Afrika Selatan maupun di Kota Medan tidak didapati mempengaruhi tingkat ICT Literasi pelajar remaja. Walaupun responden terpisahkan oleh jarak antar benua, kebiasaan dan budaya yang berbeda, namun responden tergolong dalam satu generasi yang sama-sama disebut sebagai i-gen (generasi Z). Tapscott (2009:142) menyatakan karakteristik generasi $\mathrm{Z}$ dimanapun mereka berada tetaplah sama. Sikap dan perilaku yang dapat mendefinisikan generasi $Z$ ini diantaranya: 1). Kebebasan dalam menentukan pilihan sampai kebebasan berekspresi (freedom), 2). Generasi Z ini sama-sama tumbuh dalam perkembangan teknologi dan memiliki kemampuan untuk menyesuaikan diri dalam bentuk yang mereka inginkan (customization), 3). Generasi ini juga mengharapkan integritas yang menyangkut kejujuran di dalam pengungkapan informasi (integrity), 4). Mereka berkolaborasi (collaboration) dalam membina relasi dalam kehidupan sosial. Mereka bertukar 
pikiran, cerita, pandangan, ide, pendapat dan cita-cita dalam media sosial yang mereka miliki. 5). Mereka tidak percaya akan informasi dari satu sumber, mereka sangat mencermati informasi yang diperoleh dengan mencari tau kebenaran disertai dengan bukti yang mendukung (scrutiny), 6). Remaja menjadikan media sosial dalam dunia digital sebagai bentuk hiburan (entertainment), 7). Remaja memiliki tuntutan dalam kecepatan dalam melakukan segala sesuatu (speed), 8). Mereka mengharapkan banyak inovasi dalam kehidupannya. Dalam bidang teknologi, mereka selalu menginginkan dan mencari yang terbaru (innovation).

Dalam similaritas yang dimiliki generasi $Z$ ini, peneliti mendapati beberapa poin yang dapat diukur dari butir pertanyaan yang terdapat pada kuesioner penelitian ini. Diantaranya: (1) Integrity dimiliki oleh $64.8 \%$ (245 responden) dengan menyatakan bahwa responden memberikan informasi yang akurat di setiap akun media sosial yang mereka miliki, (2) Kolaborasi dalam konvergensi media sosial digunakan oleh 61.9\% (234 responden), (3) scrutiny mendapat perhatian sangat penting bagi 83.8\% (317 responden). Mereka melakukan konfirmasi informasi yang mereka dapat dengan mencari informasi lain untuk mengetahui akurasi dari informasi tersebut sebelum mereka bagikan.

Teori Manajemen Privasi Komunikasi (CPM) yang dikembangkan oleh Petronio (2002) menyatakan bahwa individu memempertahankan dan mengkoordinasikan batasan privasi mereka dengan mitra komunikasi tergantung pada manfaat yang dirasakan dan harga yang harus mereka bayar (biaya) dalam mengungkapkan informasi tersebut. Dalam penelitian ini, peneliti melihat keterbukaan diri responden pada media sosial dengan intensitas cukup rendah (kurang dari 3 kali dalam satu hari) dimiliki oleh 81.7\% (309 responden), sementara 18.3\% (69 responden) melakukan update aktivitas media sosial lebih dari 3 kali dalam satu hari. Namun, 89.2\% (337) responden memikirkan betul apa yang mereka ingin bagikan pada media sosial mereka. Ketika mereka melakukan update pada media sosial mereka 72\% (272 responden) menyatakan tidak terbatas oleh waktu. Kapan pun mereka ingin, mereka melakukan update tanpa peduli apakah tengah malam ketika orang lain beristirahat maupun siang hari ketika orang lain sedang sibuk. 84.7\% (320 responden) menyatakan tidak sering mengungkapkan kekesalan mereka di media sosial, namun 15.3\% (58 responden) diantaranya menyatakan sering mengungkapkan hal negatif dalam akun media sosial mereka.

Dalam pengungkapan diri ini, responden tentu menimbang harga yang harus mereka bayar dengan membiarkan orang lain tau informasi yang mereka bagikan. Petronio (2002) menyatakan ada resiko yang dapat muncul dari pembukaan diri kepada orang yang salah, membuka diri pada saat yang tidak tepat, mengatakan terlalu banyak tentang diri kita sendiri 
atau berkompromi dengan orang lain. Namun pada sisi lain, pembukaan diri dapat memberikan keuntungan yang besar. Kita dapat meningkatkan kontrol sosial, memvalidasi perspektif kita dan menjadi lebih intim dengan mitra komunikasi dalam suatu hubungan ketika kita membuka diri. Untuk itu pengguna media sosial harus jeli dalam menyaring orang-orang yang menjadi bagian dalam list pertemanan kita. Pengaturan privasi dengan meneliti permintaan pertemanan sebelum menerimanya dinyatakan dilakukan oleh 245 responden (64.8\%). Dengan kata lain, responden tau betul setiap orang yang ada di dalam lingkaran media sosialnya.

Jadi, responden dikatakan mempertahankan batas privasi mereka dengan menyadari bahwa mereka harus memiliki keterampilan dalam mengelola akun di media sosial mereka dengan usaha untuk mempelajari setiap fitur untuk pengaturan privasi di dalam aplikasi media sosial, dengan ekpektasi manfaat seperti menerima respon, perasaan kagum, disukai dari apa yang mereka kirim ke akun media sosial mereka.

\section{SIMPULAN}

Ditemukan adanya korelasi positif dalam skala sedang antara Literasi Digital dan Pembukaan Diri di Media Sosial $(\mathrm{r}=0.508 \mathrm{n}=378)$ dari siswa SMA di Kota Medan dan responden memahami benar bahwa dalam pembukaan diri yang mereka lakukan di media sosial memiliki harga yang harus dibayar, dalam hal ini adalah usaha mereka untuk bisa mempelajari fitur-fitur yang ada pada media sosial guna menjaga privasi mereka.

\section{DAFTAR PUSTAKA}

Baxter, L.A. \& Braithwaite, D.O.2008.Engaging Theories in Interpersonal Communication: Multiple Perspectives. New York: Sage Publication, Inc.

Blau, I. 2011. Application Use, Online Relationship Type,Self-disclosure, And the Internet Abuse Among Children and Youth: Implications for Educational and Safety Programs. Journal Educational and Computing Research, 45(1), 95-116.

Boyd, D.M., \& Ellison, N. 2007. Social Network Sites: Definition, History, and Scholarship. Journal of Computer-Mediated Communication, 13 (1), 1-11.

Brislin, R.W. 1970. "Back-Translation for Cross-Cultural Research". Journal of Cross-Cultural Psychology. Sage Journals.

Bungin, Burhan. 2011. Metodologi Penelitian Kuantitatif. Jakarta: Prenada Media Grup.

Christensen. 2011. "You're the only person i can talk to" the role of self-disclosure in the social construction of friendship. Journal of Undergraduate Research

Eurobarometer Research of Self Disclosure between Germany and European. (20 Agustus 2011) diakses pada 3 Januari 2017 dari http://ec.europa.eu/commfrontoffice/publicopinion/archives/ebs/ebs_359_en.pdf

Hurlock, E.B. 2011. Developmental Psychology. New York : McGraw-Hill. Internet users in the world. Diunduh pada 30 November 2016 dari www.internetlivestats.com 
Stella Stefany, Nurbani, Badarrudin

Jackson \& Wang. 2013. Youth 2.0: Social Media and Adolescence: Connecting, Sharing and Empowering. Switzerland : Springer.

Jallaludin, Rahmat. 2011. Psikologi Komunikasi. Bandung: Remaja Rosdakarya.

James, J. (2014). Data never sleeps 2.0. diunduh tanggal 13 Desember 2016 dari https://www.domo.com/blog/data-never-sleeps-2-0/

Jungwirth, Bernhard. 2002. Information Overload: Threat or Opportunity? http:// citeseerx.ist.psu.edu/viewdoc/download?doi=10.1.1.461.2076\&rep=rep1\&type $=$ pdf diakses tanggal 2 April 2017

Kenalan di Facebook, SA Perkosa Siswi SMA. (13 Mei 2016) diunduh pada 13 Februari 2017 dari : http://regional.kompas.com/read/2016/05/13/09090021/ Kenalan.di.Facebook.SA.Perkosa.Siswi.SMA

Korban Penculikan Lewat Facebook (9 Februari 2010) diunduh dari http://www.viva.co.id/berita/metro/127827-korban-penculikan-lewat-facebook ditemukan

Kusumaningtyas, R.D. 2010. Peran Media Sosial Online Facebook Sebagai Saluran Self Disclosure Remaja Putri di Surabaya. Skripsi Universitas Pembangunan Negara.

Leung, L. 2006. Stressful Life Events, Motives for Internet Use, and Social Support among Digital Kids. International Communication Association (ICA) Conference for review and possible presentation. Germany.

Leung,L. 2002. Loneliness, Self-Disclosure, and ICQ (“I Seek You”) Use. CyberPsychology and Behavior: Mary Ann Liebert, Inc.

New Standards to Facilitate eLearning. 31 Maret 2009. Diakes pada 13 Desember 2017 dari https://www.eschoolnews.com/2009/03/31/new-standards-to-facilitate-elearning/

Oyedemi, T. 2014. Beyond Access : Youth and Digital Skills. South African Journal for Communication Theory and Research. ISSN: 0250-0167

Pembagian Generasi Berdasarkan Tahun Lahir (Infographics on Millennials, Gen Z, and Generations). Diunduh pada 13 November 2016 dari http://genhq.com/findings/

Petronio, S. \& Martin, J.N. 1986. Ramifications of revealing private information: A gender gap. Journal of Clinical Psychology 42 (3), 499-506

Petronio, S. 2016. The International Encyclopedia of Communication Theory and Philosophy. London, UK: Wiley-Blackwell.

Petronio, S., Martin, J., Littlefield, R. 1984. Prerequisite conditions for self-disclosing: A gender issue. Communication Monographs 51 (3), 268-273

Razali,N.M. \& Wah,Y.B. 2011. Power comparisons of Saphiro-Wilk, Kolmogorov-Smirnov, Lilliefors and Anderson-Darling tests. Journal of Statistics Modeling and Analyctics, 2(1), 2133

Riset Kominfo dan UNICEF Mengenai Perilaku Anak dan Remaja Dalam Menggunakan Internet. (6 Juli 2016). Diunduh pada 31 Maret 2017 dari

https://www.kominfo.go.id/content/detail/3834/siaran-pers-no-17pihkominfo22014tentang-riset-kominfo-dan-unicef-mengenai-perilaku-anak-dan-remaja-dalammenggunakan-internet/0/siaran_pers

Saling Ejek di Medsos, Mahasiswi Lukai Siswi SMA Pakai Silet diakses pada 13 Februari 2017 dari http://news.detik.com/berita/d-3313474/saling-ejek-di-medsos-mahasiswi-lukaisiswi-sma-pakai-silet

Singarimbun, Masri dan Sofian Effendi. 2008. Metode Penelitian Survei, Jakarta: LP3ES. 
Tapscott, D. 2009. Grown Up Digital: How The Net Generation Change Your World. New York: McGraw-Hill.

World Population Based On Generation. 2016. United States Cencus Bureau Diunduh pada 13 November 2016 dari https://www.linkedin.com/pulse/worlds-population-just-passed75-billion-here-some-fascinating-kemp

Yamane, T. 1967. Statistics, An Introductory Analysis, $2^{\text {nd }}$ Ed. New York: Harper and Row. 